\title{
How Truth Commissions Promote Accountability: An Assessment of the 1994 Zonal Commissions of Inquiry in Sri Lanka
}

\author{
Carlos Fernandez Torne
}

\begin{abstract}
This article examines how truth commissions (TCs) contribute to promoting accountability, and argues TCs generate two horizontal accountability relationships. First, TCs hold state agencies accountable. Second, recommendations made by TCs can generate a relationship of horizontal accountability between the governing regime and the state agencies towards which the recommendations are directed. Next, I present the case of the 1994 Zonal Commissions in Sri Lanka, and to assess their contribution to accountability, I compare the evidence collected against evaluative criteria. The results show that while the commissions produced answerability, recommendations compiled in the final report were not implemented. The findings show long-term effectiveness of TCs may depend on senior officers within the state apparatus in addition to political leaders.
\end{abstract}

Keywords truth commissions, horizontal accountability, state agencies, forced disappearances, evaluative criteria

\section{Introduction: Contextualizing Accountability within the Transitional Justice Field}

In transitional justice (TJ) literature, accountability commonly refers to criminal accountability; in other words, the prosecution of those responsible for violations of international human rights or humanitarian law, either in domestic or international courts. Criminal accountability emphasizes the justice side of TJ, which has been conceptualized as a "maximalist approach" (Olsen, Payne, and Reiter 2010, 16-19). From this perspective, accountability for past violations, and punishing perpetrators, is necessary to avoid the recurrence of violations and as a way to deter possible other perpetrators. Beyond trials, the TJ literature also refers to other "mechanisms of accountability," such as administrative vetting civil sanctions and truth commissions (TCs). While administrative vetting and civil 
sanctions would relate to non-criminal sanctions, TCs are considered to provide historical accountability (Kritz 1997).

TCs also establish accountability through undertaking an official investigation, publicly exposing the harm inflicted, and condemning human rights violations. By disclosing information on violations, and state institutions responsible for them, TCs hold former authoritarian regimes accountable for past violations (Olsen, Payne, and Reiter 2010, 22). TCs also establish accountability through public exposure and condemning perpetrators for their past violence. Beyond naming wrongdoers, TCs can also "compel or entice perpetrators to confess to past violence. In so doing, perpetrators subject their past violence to public scrutiny" (Olsen, Payne, Reiter, and Wiebelhaus-Brahm 2010, 460). Moreover, TCs put victims at the center of their process while documenting past abuses. Commissions collect information from the victims and listen to their stories, providing a "victim-centered process of accountability that balances political constraints with justice demands" (Olsen, Payne, and Reiter 2010, 23). In offering a forum for victims and their relatives to explain their stories, they contribute to a certain level of societal acknowledgement of their loss (Kritz 1997, 141). Through documenting individual cases of violations, TCs usually establish a formal basis for subsequent compensation of victims and, in some cases, for the punishment of perpetrators. Finally, TCs also provide an opportunity for dealing with the broader conditions under which violations took place. They examine the structural elements that made violations possible and propose institutional and legal measures to reform them.

Central to the establishment of accountability is the transfer of what has been disclosed, the new truth, to the public sphere. This can be done through a commission's interim or final report, through victims' testimonies, or through perpetrators' confessions. The final report will make public the results of the commission's fact-finding process. It is through the report that facts and evidence are explained and violations revealed, possibly leading to public recognition of the victims' suffering. Also, it is through the report that the previous regime is held accountable based on the acknowledgement that state agencies and institutions were responsible for committing violations. Finally, it is the report that exposes perpetrators through naming and shaming.

Although all these objectives could be assessed based on the extent to which a TC has contributed to promoting accountability, accountability has been approached as a means to some other goal, rather than as a goal in itself. For example, according to Brahm, it is through exposing the gruesome details of the past that TCs help usher in a new democratic era and advance the cause of human rights (Wiebelhaus-Brahm 2010, 12). In this article, I consider promoting accountability as a goal in itself rather than as a means to some other goal. On this basis, the article presents the theory of change that TCs generate vertical accountability relationships between the state and civil society and horizontal 
accountability relationships within the state. It then examines to what extent the Zonal Commissions of Inquiry established in Sri Lanka in 1994 contributed to promoting horizontal accountability. This is done through comparing the evidence collected against the set of pre-established criteria illustrated in the following section.

\section{Truth Commissions and Accountability Relationships}

I argue that truth commissions can generate vertical and horizontal accountability relationships (Fernandez-Torne 2015). Specifically, I sustain that before they are established, TCs can generate vertical accountability relationships between civil society and the governing regime. During the period between establishment of the TC and the submission of the report, TCs hold state agencies horizontally accountable through fact-finding and victim tracing functions. As a result of the recommendations in the final report, TCs generate, first, a relationship of horizontal accountability between the governing regime and the state agencies towards which the recommendations are directed. Second, TCs recommendations can also generate a vertical accountability relationship between civil society and the governing regime. This vertical accountability relationship takes place when the governing regime implements the recommendations as a result of civil society pressure.

In this article, I focus on the horizontal accountability relationships constructed during the work of a TC and as a result of the recommendations in the final report. Horizontal accountability relationships are built on the basis of state agencies legal ability to scrutinize actions by other state agencies. Specifically,

Table 1. Horizontal and Vertical Accountability Relationships.

\begin{tabular}{|c|c|c|c|}
\hline \multicolumn{2}{|r|}{ Accountability } & $\begin{array}{l}\text { Horizontal accountability } \\
\text { relationships }\end{array}$ & $\begin{array}{l}\text { Vertical accountability } \\
\text { relationships }\end{array}$ \\
\hline \multicolumn{2}{|c|}{ Before establishing a TC } & & $\begin{array}{c}\text { Civil society - governing } \\
\text { regime }\end{array}$ \\
\hline \multirow{2}{*}{$\begin{array}{l}\text { During the work of } \\
\text { the commission } \\
\text { (Actual functions) }\end{array}$} & Fact finding & \multirow{2}{*}{$\begin{array}{c}\text { Truth commission - State } \\
\text { agencies }\end{array}$} & \\
\hline & Victim tracing & & \\
\hline \multirow{3}{*}{$\begin{array}{l}\text { As a result of the } \\
\text { recommendations } \\
\text { in the final report } \\
\text { (Potentialities) }\end{array}$} & Victim redress & \multirow{3}{*}{$\begin{array}{c}\text { Governing regime - State } \\
\text { agencies }\end{array}$} & \multirow{3}{*}{$\begin{array}{c}\text { Civil society - governing } \\
\text { regime }\end{array}$} \\
\hline & Prosecutorial & & \\
\hline & Preventive & & \\
\hline
\end{tabular}

Source: Author. 
"the existence of state agencies that are legally enabled and empowered, and factually willing and able, to take actions that span from routine oversight to criminal sanctions or impeachment in relation to actions or omissions by other agents or agencies of the state that may be qualified as unlawful" (O'Donnell $1999,38)$. In relation to TCs, we can distinguish two different accountability relationships. One is the result of the actual functions a commission carries out on its own-fact-finding and victim tracing. The second is a result of the recommendations compiled in the final report, or potentialities, to keep with the terms used by the United Nations (UN) (Special Rapporteur on the Promotion of Truth, Justice, Reparation and Guarantees of Non-Recurrence 2013, para. 38).

While carrying out its actual functions, a TC investigates and reports on the principal causes and consequences of violence or repression. Through factfinding, TCs try to clarify the facts surrounding violations and the identity of perpetrators. Victim tracing entails discovering the fate of individual victims when their whereabouts are unknown. While carrying out their investigations, TCs rely on victims, witnesses, civil society groups, human rights organizations, and/or religious associations to collect information and evidence about past violations. Such information supports the commission in its interactions with state agencies, such as security forces or the judiciary. It is within these interactions with state agencies that a relationship of horizontal accountability takes place. This relationship of horizontal accountability is framed by the mandate and powers of the commission. The TC's mandate and powers also shape the extent to which it can generate answerability, defined here as the obligation of state officials to provide notice of a decision and to explain the reasons behind taking that decision. It is through holding state officials horizontally accountable that TCs generate answerability. Because TCs are authorized by the state, the truth disclosed by state officials becomes state answerability to society.

Potentialities of TCs refer to the recommendations compiled in their final report. These recommendations are a consequence of the fact-finding process, and include proposals to redress the harm done and avoid repetition. Recommendations usually include the plans for reparation programs; measures to address individual responsibility, such as removal of perpetrators from public office and/or prosecutions; and measures to reform institutions and legislation. The implementation of these recommendations, especially those related to measures of individual and institutional responsibility, emerges as a guarantee to avoid repetition of the violations committed. Once a commission submits these recommendations, it finishes its work and ceases to exist. It is the governing regime that receives the final report, the entity that has the power to compel the state agencies, such as the Attorney General's Office or the Inspector General of the National Police, to act in accordance with the recommendations. If implemented, these recommendations generate accountability in its enforcement dimension. The enforcement dimension is understood as punishment of 
improper behavior, through means such as the imposition of sanctions (Schedler 1999, 15), or through compensation and/or remediation (Fox 2007, 668-669).

\section{Evaluative Criteria to Test the Horizontal Accountability Relationships of TCs}

During the period between its establishment and the submission of the final report, a TC holds state agencies horizontally accountable. This horizontal accountability relationship produces answerability. I propose seven criteria for establishing whether or not state agencies have been rendered answerable. Three of these criteria deal with formal aspects that need to be fulfilled for the commission to produce answerability while it undertakes the fact-finding and victim tracing functions. The first is whether victims, witnesses, and/or civil society organizations can access and provide information to the commission (EC1). This entails, first, the TC reaching out to victims, witnesses, and civil society, and second, creating an environment conducive to these individuals and groups coming forward and providing information. This criterion results in the TC being able to document complaints and violations through receiving input from the public. The second criterion is whether or not the commission has access to state/ non-state actors and whether or not these actors have to be answerable to the commission (EC-2). This criterion examines the capacity of a TC to interrogate state security forces, other state agencies, and non-state actors, usually members of a politically motivated, non-state armed group responsible for conflict-related international crimes. At the same time, the criterion also examines the power of the commission to access documentation belonging to these actors to undertake fact finding and victim tracing functions. The third criterion is whether or not the final report is made public (EC-3). Such publicity is critical to transfer the answerability produced and contained in the report to the public domain.

Evaluative criteria four to seven deal with the substance of what the report needs to disclose to produce answerability. Particularly, the extent to which the report discloses new facts and evidence surrounding violations committed (EC4) and, when cases of disappearance exist, whether or not the TC has identified burial sites (EC-5). Evaluative criteria six and seven assess the extent to which a TC attributes institutional and personal responsibility for the violations committed. Particularly, whether or not the report acknowledges that state agencies and/or non-state actors committed human rights violations (EC-6), and whether or not the report attributes individual responsibility through naming perpetrators (EC-7).

In its final report, a TC makes recommendations capable of generating a horizontal accountability relationship between the governing regime and the state agencies towards which the recommendations are directed. The implementation of recommendations produces accountability in its enforcement dimension. Here, I suggest five criteria. Two of the five deal with measures intended to redress victims: whether or not reparation programs have been implemented (EC-8), 
Table 2. Criteria to evaluate answerability and enforcement.

\begin{tabular}{|c|c|c|}
\hline \multicolumn{2}{|r|}{ Accountability } & Horizontal accountability relationships \\
\hline $\begin{array}{l}\text { During the work } \\
\text { of the commission } \\
\text { (Actual functions) }\end{array}$ & $\begin{array}{l}\text { Fact-Finding } \\
\text { Victim } \\
\text { tracing }\end{array}$ & $\begin{array}{l}\text { Truth commission - State agencies: produces answerability } \\
\text { Evaluative criteria showing state agencies are being } \\
\text { rendered answerable } \\
\text { EC-1: Victims, witnesses, and/or civil society organizations } \\
\text { can access and provide information to the commission } \\
\text { EC-2: The commission has access to state/non-state actors } \\
\text { and these actors have to be answerable to the commission. } \\
\text { EC-3: The final report is made public. } \\
\text { EC-4: The report discloses new facts and evidence } \\
\text { surrounding violations committed. } \\
\text { EC-5: In case of disappearances, the TC has identified } \\
\text { burial sites. } \\
\text { EC-6: The report acknowledges that state agencies and/or } \\
\text { non-state actors committed violations of human rights. } \\
\text { EC-7: The report attributes individual responsibility } \\
\text { through naming perpetrators. }\end{array}$ \\
\hline $\begin{array}{l}\text { As a result of } \\
\text { recommendations } \\
\text { in the final report } \\
\text { (Potentialities) }\end{array}$ & $\begin{array}{l}\begin{array}{l}\text { Victim } \\
\text { redress }\end{array} \\
\begin{array}{l}\text { Prosecutorial } \\
\text { Preventive }\end{array}\end{array}$ & $\begin{array}{l}\text { Governing regime - State agencies: produces enforcement } \\
\text { Evaluative criteria for demonstrating production of } \\
\text { enforcement by the governing regime } \\
\text { EC-8: Reparation programs have been implemented. } \\
\text { EC-9: In cases of disappearances, exhumations have been } \\
\text { carried out. } \\
\text { EC-10: Alleged perpetrators are prosecuted. } \\
\text { EC-11: Perpetrators have been removed from public office. } \\
\text { EC-12: Institutional or legal reforms to prevent future } \\
\text { violations have been adopted. }\end{array}$ \\
\hline
\end{tabular}

Source: Author.

and, in cases of disappearance, whether or not exhumations have been carried out (EC-9). Two more criteria deal with issues of individual responsibility: whether or not alleged perpetrators are prosecuted (EC-10), and whether or not perpetrators have been removed from public office (EC-11). The final criterion is whether or not institutional or legal reforms to prevent future violations have been adopted (EC-12).

Table 2 summarizes these twelve evaluative criteria, and examines horizontal accountability relationships during the work of the commission and as a result of the recommendations in the final report. It includes the evaluative criteria showing when answerability and enforcement are produced. Evidence collected to assess the contribution of a TC to promoting accountability should be 
compared against this set of pre-established criteria. In the next section, I apply this framework to the commissions established in Sri Lanka in 1994.

\section{Case Study: The 1994 Zonal Commissions in Sri Lanka}

In this section, I first present an overview of the three Zonal Commissions, and next I assess the contribution of these commissions in promoting accountability. While the three Zonal Commissions of Inquiry were never called a "truth commission" in Sri Lanka, they have been considered as such by the academic literature on truth commissions, TJ experts, as well as by reports of international organizations. ${ }^{1}$

\section{The Zonal Commissions: An Overview}

Through presidential orders issued on November 30, 1994, new President Chandrika Bandaranaike Kumaratunga established three Zonal Commissions of Inquiry (COIs) into disappearances to deal with human rights violations committed since January 1, 1988 under the previous United National Party (UNP) government. ${ }^{2}$ The COIs were organized based on three geographical areas: one COI to cover the Northern and Eastern Provinces (North East Commission); another for the North Western, North Central, Central, and Uva Provinces (Central Commission); and the last for the Western, Sabaragamuwa, and Southern Provinces (Southern Commission).

Through establishing three Commissions organized around geographical areas, President Kumaratunga was also assigning them to separate armed conflicts. The Southern and Central Commissions dealt with extrajudicial killings ${ }^{3}$ and disappearances resulting from the second armed insurrection of the Janatha Vimukthi Peramuna (JVP; People's Liberation Front) from 1987 until 1989. This armed conflict ended in 1989 with the state security forces crushing the insurgency and committing widespread violations and disappearances. On the other hand, the North East Commission dealt primarily with violations resulting from the armed conflict between the government of Sri Lanka and the Liberation Tigers of Tamil Eelam (LTTE). Cases of killings and disappearances in relation to the JVP insurgency represented less than 10 percent of all the cases the North East Commission examined. Moreover, the North East Commission was only able to deal with a limited number of the overall violations as the armed conflict resumed in April 1995. ${ }^{4}$ Only 10 percent of the violations examined related to the Northern Province, which was most affected by the renewed armed conflict. Ninety percent of the complaints investigated pertained to the Eastern province. But even within the Eastern Province, most of the inquiries the Commission undertook concerned violations committed between June and December 1990, coinciding with the state security forces brutal response to the LTTE massacre of 
600 police officers.

Under the presidential orders, the three COIs had the same mandate. They were tasked to inquire into and report on persons involuntarily removed or disappeared after January 1, 1988; the evidence available to establish such alleged removals or disappearances; victims' present whereabouts; any credible material indicative of the person or persons responsible for the alleged removals or disappearances; the legal proceedings that should be taken against the persons responsible; measures necessary to prevent the occurrence of such alleged activities in the future; the relief that should be afforded to their relatives; and to make recommendations with reference to any of the previous matters (President Chandrika Bandaranaike Kumaratunga 1995). The Commissions had an initial period of four months, until March 31, 1995, to discharge the mandate. After this initial term, the mandate was extended eight times until September 3, 1997. The President appointed three commissioners to each COI including active and retired judges, lawyers, and academics.

The Central Commission received 15,045 complaints in total and was able to investigate 6,443 of them. The remaining 8,602 were handed over to the All Island Commission, a commission established in 1998 to inquire into the disappearances left unexamined by the three Zonal Commissions. The Southern Commission received 8,739 complaints of disappearance, of which it inquired into 7,761 and established 7,239 cases of involuntary removal or disappearance as defined by the mandate. The North East Commission inquired into 2,815 cases. ${ }^{5}$ Over 90 percent of these $(2,610)$ correspond to three districts in the Eastern region: Trincomalee (614), Batticaloa (1,219), and Ampara (777).

The three Commissions made recommendations in the three areas examined in this article: reparations, prosecutions, and measures intended to prevent recurrence. With regards to reparations, the commissions recommended the payment of compensation to the relatives of the disappeared with amounts that exceeded those the government finally provided. They also recommended scholarship programs for the education of children of the families of the disappeared. As for the existence of mass graves, the Southern Commission recommended developing training on skills needed to disinter mass graves with the assistance of international agencies (Southern COI 1998, chapter 14).

The Commissions also recommended prosecuting perpetrators. Acknowledging the fact that causing the disappearance of a person is not an offense under Sri Lankan law, the Central Commission recommended prosecutions on account of acts that constitute the ingredients of a disappearance, such as arbitrary arrests, unlawful detention, and failure to produce before a court of law. Both the Central and Southern Commissions recommended appointing a team of investigators formed by police officers from the criminal investigation department and a team of state counsel officials to assist these investigators with their work.

As measures to prevent the repetition of killings and disappearances, all 
three Commissions recommended a general review of emergency regulations relating to arrest and detention of persons. They called for stricter requirements on security officers in relation to arrest records, detention, and transfer and release of detainees. The Commissions also called for provisions to increase the transparency of the process including informing relatives of the detainee and recording the name and rank of the arresting officer, the time and date of arrest, and the place of detention, as well as informing the arrestee of the reasons for the arrest.

Assessing the Contribution of the Zonal Commissions in Promoting Accountability In this section, I evaluate the contribution of the Zonal Commissions in promoting accountability. I compare the evidence collected through semistructured interviews and documentary sources against the criteria proposed to assess accountability. Following the framework presented above, criteria one to seven correspond to the answerability produced as a result of horizontal accountability relationships during the work of the Commissions, and criteria eight to twelve correspond to enforcement as a result of horizontal accountability relationships following the recommendations in the final report.

Answerability as a result of horizontal accountability relationships during the work of a TC (EC 1-7): In interactions with victims, witnesses, and broader civil society, state answerability is produced when TCs disclose evidence of state violations. For the state to be rendered answerable in the first place, victims, witnesses, and/or civil society organizations need to access and provide information to the commission (EC-1). Through interactions with victims and civil society organizations, the three Zonal Commissions received around 30,000 complaints, out of which they were able to inquire into over 17,000.

The environment where each Commission operated was different. For the Central and Southern Commissions, the environment was generally conducive for victims and families of the disappeared to come forward, despite some cases of intimidation and threats by security forces. The need to protect witnesses led the Presidential Secretariat to issue a directive in February 1996 and send those officers interfering in the proceedings of the Commissions on compulsory leave. This was not the case for the North East Commission as the ceasefire between the government and the LTTE declared in January 1995 was broken in April 1995 and intense fighting resumed. Thus, while victims, witnesses, and civil society organizations were able to access and provide information to the Southern and Central Commissions, this was not the case for the North East Commission due to the ongoing war. Consequently, EC-1 was partially met.

State answerability is also produced as a result of the horizontal accountability relationship between a TC and state agencies. For state agencies to be rendered answerable, the commission has to have access to state actors, and these actors 
have to be answerable to the commission (EC-2). The three Commissions had access to the police and the Army, though unevenly. While Commissioners were able to collaborate to some degree with the police, they met a wall of silence when approaching the Sri Lankan Army.

With regards to the police, the Commissions undertook an exhaustive factfinding mission to corroborate the evidence collected from victims' relatives and witnesses. As a result of a request by the Southern Commission, President Kumaratunga directed the Inspector General of Police to order all officers-incharge of police stations to preserve information books, telephone registers, prisoner detention registers, and other documents connected with arrests and detentions since January 1, 1988 (Inspector General of Police 1995). Meal registers proved to be critical evidence as they had recorded food given to detainees even if their arrests and detentions had not been recorded. Similarly, charts of police and other government vehicles were key to track trips to villages and other locations around the time when disappearances had taken place. Through such fact-finding, the Commissions produced answerability as a result of the horizontal accountability relationships with the police.

As for the Army, the Commissions' attempts to collect information met little success. For instance, when the Southern Commission inquired about fortythree army camps revealed by witnesses, the Army provided information on only eight camps, arguing they lacked records (Southern COI 1998, annexures, 199). Lack of records was the recurrent response by the Army also in relation to meal registers, records regarding the release and transfer of detainees, and the names of persons to whom the detainees were released. Still, the North East Commission found substantial corroborative evidence as most of the arrests by the Army were made in full public view with many witnesses (North East COI 1998, 61). In one instance, the North East Commission requested an army commander conduct an internal inquiry. The military court found that there was inadequate evidence because the Army had not maintained proper records during the relevant period. The military court considered it understandable due to the intense terrorist activities which had halted the administrative machinery (ibid., chapter 2). The final report of the North East Commission expresses the frustration of the Commissioners: "The fact is that the Army arrested people in large numbers. The Army only can answer what happened to the corpus of those arrested. It was no use denying that they have nothing to do with these arrests" (ibid., 62).

The Commissions had access to both the police and the Army, and they were answerable to the Commission. However, while the Commissioners had access to documentation that allowed them to cross-examine actions undertaken by the police, this was not the case for the Army. This resulted in the Commissions being much more successful in the fact-finding done in relation to the police compared to the Army. However, because the Commissions did have access to the police and the Army, and because these security agencies were answerable to 
the Commissions, I conclude EC-2 was fulfilled.

The publication of the final report transfers the state answerability resulting from the fact-finding to the public domain. Hence, one criterion for evaluating answerability is whether or not the final report is made public (EC-3). The three Commissions' final reports were submitted in September 1997. The government published them in February 1998 as separate volumes. In the case of the Southern Commission, a second volume was later submitted and published in April 1998.

While the government made the reports by the three Commissions public, they were not widely circulated. In a 1999 report, the United Nations Working Group on Enforced and Involuntary Disappearances (WGEID) refers to the fact that the reports "were available from the Government Publications Bureau albeit only in a very limited number" (WGEID 1999, para.16). As various sources indicate, relatives of the victims and those who appeared before the Commissions were not informed of the findings of the Commissions (ibid.; Pinto-Jayawardena 2010a, 87-88). As a representative of the local peace committee in Baticaloa mentioned, "nobody here, not victims nor civil society organizations, got to know about the content of the reports" (interview with Hapuarachchi 2015). It is not clear why human rights organizations or victim groups failed to publish summaries of reports with the key findings of the Commissions.

Once the report is made public, we can evaluate the scope of state answerability. Evaluative criterion four assesses the extent to which the report discloses new facts and evidence surrounding violations committed (EC-4). Based on the information provided by the relatives of those disappeared and collected by examining documentation and records of the police, the three Zonal Commissions were able to disclose new facts and evidence surrounding involuntary removals, disappearances, and extrajudicial killings.

As previously unacknowledged facts by the state, the Commissions established around 16,500 cases of involuntary removal or disappearance, including abductions followed by subsequent killings where the corpora were found. The Commissions concluded that those who disappeared were dead. The final report of the Southern Commission mentions that "disappearance following an abduction is in our finding only a euphemism for a killing, a reality that the absence of recovery of the body should not be allowed to obscure" (Southern COI 1998, chapter 5). The Central Commission found security forces had run eight torture chambers where persons removed were confined. In Kandy District, the Commission found a college that had been used as a detention camp by the police's Counter Subversive Unit. According to the evidence collected, "about 1,000 persons were detained in this camp and systematically tortured before being taken away and killed" (Central COI 1997, interim report II).

Another previously unacknowledged fact by the state was the finding of the political dimension of disappearances. The Central and Southern Commissions found a clear link between the political conflicts and disappearances in areas 
where the JVP insurgency was active. The Central Commission found enough material "to indicate that most of the victims were organizers of the Sri Lanka Freedom Party" (Central COI 1998, 5), the opposition political party during the UNP government. According to the Commission, "such persons were branded as subversives [members of the JVP], and their names given to the police and armed forces for elimination" (ibid.). Consequently, the security forces were used to advance the interests of certain politicians.

Concerning the evidentiary standards, the Commissions were mandated to collect evidence indicative of the person responsible, not evidence beyond a reasonable doubt as in a court. Fact-finding through available documentation disclosed new evidence surrounding violations committed. The Secretary of the Central Commission recalls examining the victims' testimonies with the entries in the information books maintained by the police. He expressed:

Victims said persons who appeared to be police officers had come home and taken their children away. In the [police] information books, no such entries were there. No entry in [the] detention register. But [the meal] register had entries of the person who had disappeared having been given a meal on that day. Running charts of police vehicles confirmed travel to the particular village. We immediately concluded there is evidence indicative that the officer in charge of the police station was responsible (interview with Iqbal 2014).

From the evidence collected, I conclude the Zonal Commissions fulfilled EC-4 as the Commission's final reports disclosed new facts and evidence surrounding violations committed.

Evaluative criteria five examines whether or not a TC has identified burial sites (EC-5). The Central Commission recorded evidence of mass graves on the basis of information provided by complainants (personal communication with Secretary Central COI Iqbal 2017). The Southern Commission's final report referred to the existence of twelve mass graves and acknowledged that there were many more known to the local people. Where testimonies based on firsthand knowledge existed, the Commission recorded the existence, locations, and identities of bodies alleged to be buried in these graves (Southern COI 1998). As for the North East Commission, the report does not refer to the identification of burial sites. I conclude EC-5 was only partially met as the Commissions did not have a clear mandate to locate burial sites and they only collected evidence on the basis of information witnesses provided.

Attribution of institutional and individual responsibilities also indicates the scope of the answerability produced. With regards to institutional responsibility, if the report acknowledges that state agencies and/or non-state actors committed violations of human rights (EC-6), it is producing more answerability.

The three Commissions refer to police and Army officers as responsible for involuntary removals or disappearances. Moreover, the North East and the 
Southern Commissions also identified subversives as perpetrators. The North East Commission found 90 percent of cases it investigated attributable to the security forces (Army, Navy, Air Force, and police), while the LTTE was also responsible for its own share of removals (North East COI 1998, 62). The Southern Commission found that petitioners identified perpetrators in 5,696 out of the 7,239 cases where disappearance was proved. Among these 5,696 cases, 4,858 (85.2 percent) petitioners identified agents of the state or paramilitary groups as collaborators. The subversive groups were identified as perpetrators in 779 cases (13.7 percent) (Southern COI 1998, chapter 4). In addition to the security forces and the subversive groups, the Central and the Southern Commissions also refer to the UNP political leaders as responsible for disappearances. Consequently, I conclude EC-6 was fulfilled as the three Commissions' reports acknowledged that state agencies and non-state actors had committed violations of human rights.

With regards to whether or not the report attributed individual responsibility through naming perpetrators (EC-7), the three Zonal Commissions adopted a different approach. The Southern Commission did not name names on the grounds that the evidence was collected ex-parte without cross-examining alleged perpetrators. The Commission submitted a list of over 600 perpetrators to the President under a separate file which was not published.

On the contrary, the interim reports of the Central Commission included the name of fifteen alleged perpetrators. The Central Commission also sent a confidential list under a separate cover to the President with the names of persons deemed responsible in 1,396 cases of disappearance. The final report of the North East Commission names ten Army and police officers against whom there was evidence for initiating prosecution (North East COI 1998, 62). Furthermore, the report also names officers against whom there was evidence available in relation to forty-eight cases of disappearance (ibid., annexure E). Again, EC-7 was only partially fulfilled. While the Central and North East Commissions included some names of alleged perpetrators in their final reports, lists with hundreds of names were confidentially sent to the President in separate documents and never published.

Enforcement as a result of horizontal accountability relationships after the recommendations (EC 8-12): President Chandrika Bandaranaike Kumaratunga was the President of Sri Lanka from November 1994 to November 2005. As the former Secretary of the Central Commission wrote:

That even the President who appointed the Commissions of Inquiry into disappearances had not been serious about the issues involved and the recommendations made is seen from the fact that none of the four reports of the Commissions have been placed before the Parliament for a full discussion on them to enable the Parliament to take action on the recommendations contained in them and 
to raise public awareness of the issues (Iqbal 2004a).

A criterion to assess fulfillment of the enforcement dimension of accountability is whether or not reparation programs have been implemented (EC-8). The three Commissions found family members were in dire situations as the breadwinner had been disappeared in most cases.

The amounts provided by the government as compensation were less than those recommended by the Commissions. Under a 1988 program called "Payments of Compensation to Most Affected Persons," the Ministry of Rehabilitation and Reconstruction provided LKR\$ 50,000 (US\$ 800) for the death of a married man; ${ }^{6}$ LKR $\$ 25,000$ (US\$ 400) for the death of an unmarried person; and LKR\$ 15,000 (US\$ 240) for the death of a minor. An ex-gratia payment was given to the families of public officers of up to LKR $\$ 150,000$ (US\$2,400) and payment of the full salary and allowances of the deceased officer until he would have reached 55 years of age. Finally, LKR\$ 500,000 (US\$ 8,000) was provided for the death or disappearance of a politician (personal communication with Secretary of Central COI Iqbal 2017). Nevertheless, the Rehabilitation of Persons, Properties and Industries Authority tasked to provide the payments sometimes did not do so, alleging non-allocation of funds by the Ministry of Treasure (Iqbal 2004b). Although the three Commissions made extensive recommendations on reparations, the families of the victims only received a limited amount of monetary compensation. Thus, I conclude EC-8 was only partially met. Only some relatives of those killed or disappeared received compensation, and the implementation of reparation programs ended there. As a result, very few of the whole range of recommendations intended to redress victims were effectively implemented and produced enforcement.

A specific criterion to assess the production of enforcement in commissions looking into disappearances is whether or not exhumations have been carried out (EC-9). Even though the Southern Commission recommended developing training in the requisite skills with the assistance of international agencies, this was never done. Not even the recommendation to collect information on the existence of mass graves, their locations, and identities of bodies alleged to be buried was implemented (Southern COI 1998, chapter 14).

With regards to individual responsibility, there is enforcement if prosecutions have taken place (EC-10). As mandated, the Commissions collected and presented, in their reports, evidence indicative of the persons responsible for violations. Such evidence was not intended to prove the guilt of the alleged perpetrators in a criminal proceeding, but to facilitate and direct the work of the police investigation. To safeguard the independence of the investigators, both the Southern and Central Commissions recommended appointing a special police unit for such investigations. As a result, in November 1997, the government established the Disappearances Investigation Unit (DIU) under the Deputy 
Inspector General of Police of the Criminal Investigations Department (All Island Commission 2002, 15). The DIU was to conduct criminal investigations by collecting evidence in addition to that presented by the Commissions, and send the cases to court. Data concerning cases investigated, criminal proceedings started, and number of convictions is available through UN reports.

The first reference to prosecutions as a result of the three Zonal Commissions is in the 1999 report from the WGEID. The report mentions the Commissions identified suspected perpetrators in relation to 3,861 cases of disappearance, and that the DIU had started investigations against 1,560 suspected perpetrators, including members of the police and armed forces (WGEID 1999, para. 34). The report further refers to the establishment of the Missing Persons Unit (MPU) (the unit in charge of cases of disappearance within the Attorney General's office) on July 14, 1998, and to the fact that the MPU had received dossiers relating to 890 cases of disappearance from the DIU. The task of the MPU was to consider the initiation of criminal proceedings against perpetrators. The report further refers to the fact that criminal proceedings had started against 486 persons in relation to 270 cases of disappearance as of October 1, 1999. As enforced disappearance was not a criminal offense under Sri Lankan criminal law, criminal proceedings were brought forth on other offenses such as abduction with intent to murder, wrongful confinement, torture, rape, or murder. The report also highlights that the first of the accused, a police officer, was convicted for the crime of abduction and sentenced to five years of imprisonment on September 14, 1999 (WGEID 1999, para. 35).

The next reference to prosecution as the result of the recommendations by the three Commissions is in the fourth periodic report submitted by the government to the Human Rights Committee. The report refers to the DIU having completed, as of December 31,2000, criminal investigations of 1,175 cases out of 1,681, and having sent the notes of the investigations to the MPU. The report refers to criminal proceedings having started against 597 security forces personnel in relation to 348 cases (Government of Sri Lanka 2002, para. 156-160). This represents an increase of criminal proceedings against 111 new members of the security forces in relation to seventy-eight new cases compared to the 1999 report of the WGEID (1999, para. 35).

The last official data available appears in the report submitted by the government to the Committee against Torture. However, the report excludes data from the North East Commission without any explanation, and includes data from the All Island Commission and the Board of Investigation for Jaffna established in 1996. According to this report, the DIU conducted investigations on 3,615 cases. Of these, 2,462 cases had been completed and the relevant files of 2,095 cases had been forwarded to the Attorney General, on whose advice 1,033 cases have been closed. Investigations with regard to 256 cases could not be continued due to insufficient evidence. The data provided indicates that 
432 cases were filed, with 178 concluded and 247 pending. In this report, the government does not provide the total number of personnel against whom criminal proceedings had started. The report mentions that while twelve of the accused had been convicted, 130 had been acquitted (Government of Sri Lanka 2004, para. 63-64). There is no indication of how many of these cases mentioned in the report overlap with those mentioned in the report to the Human Rights Committee or the report by the WGEID.

The 2004 report refers to twelve convictions and 130 acquittals (ibid.), while the 1999 report estimates investigations against 1,560 suspected perpetrators (WGEID 1999, para. 34). The former Secretary of the Central Commission refers to these cases as a government strategy to deal with international pressure at the United Nations. According to him:

The government has to give an account of what happened to the Commissions' report. What action did you take? They have to say we have started so many prosecutions; cases are pending before the courts; then nobody can pressurize. That is why at every [United Nations] session they used to give figures; to give figures they must have some cases filed (interview with Iqbal 2014).

By 2002, at least 348 cases were filed against 597 security forces personnel in response to the recommendations of the three Zonal Commissions, with notes of investigation concerning hundreds of other cases at the MPU ready to be filed. The government used various strategies to attenuate the number of cases to be filed and that of convictions. One way to reduce the number of cases to be filed was inaction by the MPU. When the DIU sent the notes of investigation to the MPU alleging insufficient evidence to take the investigation further, this was accepted without any objection (Pinto-Jayawardena 2010a, 101). In this way, the Attorney General turned down many cases on the grounds of insufficient evidence.

The cases actually filed with courts were usually against junior officers. One reason for this is that the DIU would simply not return the files relating to senior officers to the MPU, claiming investigations were incomplete. As one report noted, "such delays are said to result from 'considerations of brotherhood.' Investigators are especially likely to protect senior officers at the expense of juniors" (Asian Legal Resource Center 2002). Another report goes further to state that "those police officers who investigated their superior officers in this regard too zealously were transferred out of the DIU or penalized in some other way" (Pinto-Jayawardena 2010a, 101). The 2015 report of the OHCHR investigation on Sri Lanka further highlights this saying, "most of the cases referred to courts involved alleged perpetrators of a low rank in the police and military. Since DIU itself consisted of police officers, credible sources told [the investigators of $\mathrm{OHCHR}$ ] that it was reluctant to pursue investigations against superior officers" 
(OHCHR 2015, para. 503).

At the same time, the number of people convicted remained low. Yasantha Kodagoda, Senior State Counsel at the MPU, stated that the convictions rate was as low as 5 percent (interview with Kodagoda 2015). Referring to the low number of convictions, the Human Rights Committee pointed to the lack of satisfactory evidence and unavailability of witnesses. It also recommended that the authorities "diligently enquire into all cases of suspected intimidation of witnesses and establish a witness protection program in order to put an end to the climate of fear that plagues the investigation and prosecution of such cases" (Human Rights Committee 2003, para. 9).

Another strategy to decrease the number of convictions was through cross-examining victims. At the time disappearances were taking place, the police had refused to accept complaints. Only after the Commissions were appointed in 1994 was a directive issued to the police to accept complaints, even in respect to incidents that had happened long before. Consequently, most of the complainants who appeared before the Commissions produced copies of complaints made to the police long after the incident occurred, which the Commissions accepted. These complaints had to be annexed to the applications for compensation provided by the state (personal communication with Secretary of Central COI Iqbal 2016). In these complaints, the victim petitioners had been asked not to refer to the identity of the perpetrator, but rather to state that the perpetrators were unknown. In this regard, the Chairperson of the Southern Commission stated, "references to anyone by name entailed having to go through a prosecution" (interview with Muttetuwegama 2014). Similarly, the official government forms which have to be signed to receive compensation actually stated that perpetrators were "subversive" or "unknown." Hence, by signing this form, victims would be acknowledging that they did not know who perpetrated the crime (Pinto-Jayawardena 2010a, 102).

When those cases were filed and victims were testifying about the identity of the perpetrators, the defense counsel used their earlier statement on the compensation form to impugn their credibility. Mr. Kodagoda referred to this technical problem stating:

Some of these people, either due to the security situation that prevailed at that time or due to the need to get compensation, had, previous to these Commissions, also made statements to the police as well as to civil administrators saying that their so-and-so had been abducted and had disappeared and they did not know the identities of the abductors. Several years down the road, they had told the Commission or the DIU the identities of the perpetrators. So, on the face of it, there was sufficient material to cross-examine the witnesses, so their testimonial trustworthiness was seriously in doubt (interview with Kodagoda 2015).

The problem here is that state agencies, the police, the Attorney General, 
and the judiciary did not see the outcome of the fact-finding done by the Commissions as a reference point from which the police could further investigate for the Attorney General to build stronger cases. Rather, they saw the Commissions' findings as information that needed to be crosschecked and, if and when contradictions came up, use it as grounds to drop the cases. Two reasons justify this approach: judicial attitudes and the war between the government and the LTTE in the Northeast, which restarted in April 1995 after negotiations for a peace agreement failed.

In relation to judicial attitudes, some within the judiciary felt extra-judicial elimination of insurgents was necessary to restore security and normalcy in the country. A report points at institutional and motivational factors within the prosecutorial and judicial system to explain the low rate of convictions. The report refers to an interview with a former senior state counsel who is quoted as saying:

The attitude of counsel, courts and the accused sometimes make our work difficult. The attitude seems to be that if the police/Army had not resorted with such force against subversives at that time, our society will not have survived that era. Hence what is done is believed to be justified. Some believe that the police officers were only doing their job. Some judges are also biased by the personal experiences that they have had to undergo during this period (Pinto-Jayawardena 2010a, 101).

The ongoing war in the Northeast was another reason interviewees justified the low rate of convictions. A former Commissioner of the Southern Commission stated that "the war was not over. Some perpetrators went from the South to the North [to fight]. In a situation where the war is not over, even the government cannot really take action against the higher ups" (interview with Jayawardena 2014). Thus, I find that EC-10 was not fulfilled. The state agencies did not work towards implementing the Commissions' recommendations for prosecution, and, as a result, the enforcement produced was very limited.

Another measure concerning individual responsibility that demonstrates enforcement is whether or not perpetrators have been removed from public office (EC-11). The Southern Commission recommended interdiction of officers following initiation of criminal proceedings (Pinto-Jayawardena 2010b, 94). According to the lawyer of a victim's group:

Some officers were interdicted, but widely the government, the [Inspector General of Police], by an order circular, lifted this interdiction and they were reinstated. In a case filed by us, the Court of Appeal held that [the reinstatement] was illegal and they were again interdicted. But we do not know what happened then after, the government changed (interview with Kumarage 2015).

Indeed, the Deputy Inspector General on Personnel and Training of the 
police issued a circular directing the reinstatement of all officers interdicted following inquiries conducted by the DIU and charged in courts but subsequently released on bail. However, the circular was eventually quashed, as the Court of Appeal understood that, on the basis of the Establishment Code, officers against whom criminal proceedings had started should not be reinstated (PintoJayawardena 2010b, 94, fn. 124). However, recommendations by the Central and Southern Commissions to initiate disciplinary actions against government officials were not implemented. Consequently, I conclude EC-11 was not fulfilled.

Evaluative criteria twelve considers whether or not institutional or legal reforms to prevent future violations have been adopted. Most of the recommendations made by the Commissions to prevent future violations concerned reviewing emergency legislation related to arrest and detention. The government did not implement most of them. Thus, it must be found that EC-12 was not fulfilled.

\section{Explaining Lack of Enforcement after the Recommendations}

The previous analysis shows that while the Commissions produced answerability as a result of horizontal accountability relationships with state agencies, the recommendations compiled in the final reports did not lead to enforcement. To explain the lack of enforcement following the recommendations, I examine the responses from the state agencies to the Commissions' recommendations to prosecute. In the context of Sri Lanka, the state apparatus worked as a system to protect itself against a change of political leaders at the top. The state apparatus' self-protection mechanism entailed actions (and inactions) to reduce the number of cases filed and to lower the rate of convictions when prosecutions went ahead. To meet these ends, first, state agencies did not treat the investigation results by the Commissions as a basis for prosecutions. Rather, they treated such findings as information that needed to be crosschecked, and, if and when contradictions came up, as grounds to drop those cases. Second, intimidation of witnesses amidst a climate of fear plagued the investigations and prosecutions of these cases. Third, inaction on the part of the MPU after accepting, without any objection, the DIU's allegations of insufficient evidence also contributed to a lower number of cases being filed. At court, victims serving as witnesses were cross-examined based on lacunas in their statements given to the Commissions years before about incidents that had taken place sometimes as many as ten years earlier. Victim's credibility was also impugned on the basis of official forms on which they were forced to allege ignorance of the identity of the perpetrators in order to receive compensation.

Various factors led state agencies to act as a system of self-protection. The Sri Lankan Army and the police agreed with the Commissions' findings that the political leaders from the previous regime were responsible for directing the security forces to disappear people on the grounds they were insurgents. However, 
those political leaders were not brought to justice. Those prosecuted were officers of the security forces, mainly police personnel. Faced with the prospect of prosecuting their own personnel while the real culprits (political leaders) escape, the security forces, including the police, must have acted to protect themselves. Second, considerations of brotherhood within the police also worked to that effect. Officers of the DIU were investigating their colleagues. Consequently, when criminal proceedings were initiated against police officers of a higher rank, investigations appear to have concluded that the cases reached a dead end. Only cases against junior officers were sent to the MPU to initiate criminal proceedings. Third, some prosecutors, judges, and the accused themselves tended to legitimate the response of the security forces on the grounds that if they had not responded to the armed insurgency as they did, Sri Lankan society would not have survived that time period. Finally, many interviewees pointed to the ongoing war in the North and East of the country against the LTTE as justification for the low rate of convictions. What the previous analysis shows is the failure of the institutional response (the establishment of the DIU and the MPU) to punish those responsible. Lack of punishment entailed leaving the perpetrators within the security forces, especially in the Sri Lankan Army.

\section{Conclusion}

I have analyzed two horizontal accountability relationships: first, between a TC and the state agencies during the work of a TC, and, second, between the governing regime and state agencies as a result of the recommendations in the post-report period. With regards to the former, the evaluation has shown that the three Zonal Commissions generated horizontal accountability relationships as a result of their interactions with security forces. Specifically with the police, the Commissions were able to conduct an exhaustive investigation through accessing various police information books. However, the Commissions were not successful in holding the Army horizontally accountable as it continuously refused to provide information. Overall, COIs were successful in their fact-finding work that produced state answerability through disclosing evidence in support of violations committed by security forces and politicians.

Nevertheless, it is not enough to produce answerability; this answerability needs to be transferred to the public domain. Through the COIs, the new governing regime held the old system accountable. But exposure of the old regime to the new government through a TC should also be an exposure of the old regime to the citizens once the TC's report is released to the public. Here, the government failed to transfer that answerability to the public domain. And, civil society organizations, especially human rights organizations and victim groups, possibly failed to compensate for the lack of action by the government through 
publishing summaries of reports with the key findings of the Commissions.

Regarding the second horizontal accountability relationship between the governing regime and state agencies, few of the Commission's recommendations resulted in enforcement. While small amounts of money were provided as compensation to victims and families, most of the recommendations to redress victims' suffering were not implemented. Neither recommendations to collect information on the location of mass graves, nor calls to exhume burial sites and identify bodies were implemented. Recommendations to prosecute those responsible produced extensive answerability from the various state agencies concerned, but limited enforcement. Extensive answerability was established as the DIU investigated thousands of cases on the basis of the outcomes of factfinding surveys done by the Commissions, and this led to the MPU starting criminal proceedings against 597 security forces personnel. But limited enforcement was realized as only twelve perpetrators out of 597 security forces personnel prosecuted were convicted as of 2004, most of them junior officers. Finally, the government did not implement most of the recommendations intended to remove perpetrators from public office or to adopt institutional or legal reforms to avoid repetition.

The analysis of the impact of the three Commissions shows that, while the Commissions produced answerability during its work as a result of horizontal accountability relationships with state agencies, the recommendations compiled in the final reports did not lead to enforcement. The response of state agencies to the Commissions' recommendations to prosecute shows investigative and prosecutorial agencies working towards self-protection. These developments indicate that the long-term effectiveness of a TC may depend not only on the willingness of political leaders in the new regime, but also on the senior officers within the state apparatus.

\section{Notes}

1. Some of these include Amnesty International 2010; Backer 2009; Bakiner 2014; Brahm 2009; Dancy, Kim, and Wiebelhaus-Brahm 2010; Freeman 2006; Hayner 2002, 2011.

2. I examine the 1994 Zonal Commissions but not the 1998 All Island Commission, which was established to follow up on cases left unaddressed by the 1994 COIs. I limit my analysis to the Zonal Commissions as these were established immediately after the electoral victory of President Kumaratunga, which ended seventeen years of United National Party presidential rule and allowed for the transition to unfold. Nonetheless, where appropriate, I have made reference to the work of the All Island Commission.

3. Although the Commissions had the mandate to inquire into involuntary removals and disappearances, it also looked into extrajudicial killings.

4. The war resumed in the Northern province when LTTE broke the January 1995 cease- 
fire on April 19, sinking two patrol boats and shooting down two troop transport planes, killing ninety-seven people.

5. As opposed to the other two Commissions, the North East Commission's final report does not provide the total numbers of complaints received and how many of those were effectively investigated. The figure of 2,815 is calculated based on the number of complaints investigated, when this number appears in the corresponding district chapter, and the list of complaints inquired which appears in the annexures for some other districts.

6. Average exchange rate years 1996-1999: \$US $1= \pm$ LKR $\$ 62.5$.

\section{Appendix: List of Interviewees}

\section{Former Commissioners and Committee Members}

1. Manouri Muttetuwegama. Chairperson, COI into the Involuntary Removal or Disappearance of Persons in the Western, Southern, and Sabaragamuwa Provinces. October 24, 2014, Colombo.

2. Amal Jayawardena. Commissioner, COI into the Involuntary Removal or Disappearance of Persons in the Western, Southern, and Sabaragamuwa Provinces. October 24, 2014, Colombo.

3. MCM Iqbal. Secretary, COI into the Involuntary Removal or Disappearance of Persons in the Central, North Western, North Central, and Uva Provinces. July 9, 2014, Amsterdam.

\section{Governing Regime}

4. Yasantha Kodagoda. Senior State Counsel, Missing Persons Unit, Attorney General's Office. July 3, 2015, Colombo.

\section{People Supporting Victims}

5. Chandra Pala Kumarage. Legal advisor of the Organization of Parents and Family Members of the Disappeared. July 1, 2015, Colombo.

6. Amara Hapuarachchi. Peace Committee in Batticaloa. July 6, 2015, Batticaloa.

\section{References}

All Island Commission. 2002. Final Report of the Commission of Inquiry into Involuntary Removal and Disappearance of Certain Persons (All Island). Colombo: Government of Sri Lanka.

Amnesty International. 2010. "Commissioning Justice: Truth Commissions and Criminal Justice.” POL 30/004/2010, April 26. https://www.amnesty.org/en/documents/ pol30/004/2010/en/ (accessed October 27, 2017).

Asian Legal Resource Center. 2002. "Written Statement to the Commission on Human 
Rights, 58th Session, Item 11(b): Civil and Political Rights, including Questions of Disappearances and Summary Executions, Sri Lanka." March 4. http://alrc.asia/ disappearances-in-sri-lanka/ (accessed November 9, 2017).

Backer, David. 2009. "Cross-National Comparative Analysis." In Assessing the Impact of Transitional Justice: Challenges for Empirical Research, eds. Hugo Van Der Merwe, Victoria Baxter, and Audrey R. Chapman, 23-90. Washington, D.C.: United States Institute of Peace.

Bakiner, Onur. 2014. "Truth Commission Impact: An Assessment of How Commissions Influence Politics and Society." The International Journal of Transitional Justice 8: 6-30.

Brahm, Eric. 2009. "What is a Truth Commission and Why Does it Matter?" Peace and Conflict Review 3 (2): 1-14.

Central COI (Commission of Inquiry). 1997. Interim Reports of the Commission of Inquiry into the Involuntary Removal or Disappearance of Persons in the Central, North Western, North Central and Uva Provinces. Colombo: Government of Sri Lanka.

Central COI (Commission of Inquiry). 1998. Final Report of the Commission of Inquiry into the Involuntary Removal or Disappearance of Persons in the Central, North Western, North Central and Uva Provinces. Colombo: Government of Sri Lanka.

Dancy, Geoff, Hunjoon Kim, and Eric Wiebelhaus-Brahm. 2010. “The Turn to Truth: Trends in Truth Commission Experimentation.” Journal of Human Rights 9 (1): 45-64.

Fernandez-Torne, Carlos. 2015. "Truth Commissions and the Accountability Relations They Generate: A New Framework to Evaluate Their Impact." Asian Journal of Peacebuilding 3 (2): 233-251.

Fox, Jonathan 2007. "The Uncertain Relationship between Transparency and Accountability." Development in Practice 17 (4/5): 663-671.

Freeman, Mark. 2006. Truth Commissions and Procedural Fairness. New York: Cambridge University Press.

Government of Sri Lanka. 2002. "Fourth Periodic Report, Sri Lanka United Nations, Human Rights Committee." CCPR/C/LKA/2002/4, October 18. http://www.refworld. org/docid/3efb5b894.html (accessed October 27, 2017).

Government of Sri Lanka. 2004. "Second Periodic Report of States Parties due in 1999, Addendum, Sri Lanka." Geneva: United Nations, Committee Against Torture.

Hayner, Pricilla. 2002. Unspeakable Truths: Facing the Challenge of Truth Commissions. New York: Routledge.

Hayner, Pricilla. 2011. Unspeakable Truths: Transitional Justice and the Challenge of Truth Commissions. New York and London: Routledge.

Human Rights Committee. 2003. "Concluding observations of the Human Rights Committee, Sri Lanka." CCPR/CO/79/LKA, December 1. https://www.reproductiverights. org/sites/default/files/documents/XSL_CO.Sri\%20Lanka2003E.pdf (accessed October 27, 2017).

Inspector General Of Police. 1995. Circular No. 1187/95, Retention of Information Books etc.

Iqbal, M. C. M. 2004a. "Commissions and Committees on Disappearances. What Next?" http://www.ruleoflawsrilanka.org/resources/writings-of-m-c-m-iqbal/commissionsand-committees-on-disappearances (accessed June 25, 2014).

Iqbal, M. C. M. 2004b. “Reparations to Victims of Disappearances.” http://www. ruleoflawsrilanka.org/resources/writings-of-m-c-m-iqbal/reparations-to-victims-of- 
disappearances (accessed June 25, 2014).

Kritz, Neil J. 1997. "Coming to Terms with Atrocities: A Review of Accountability Mechanisms for Mass Violations of Human Rights." Law and Contemporary Problems 59 (4): $127-152$.

North East COI (Commission of Inquiry). 1998. Final Report of the Commission of Inquiry into the Involuntary Removal or Disappearance of Persons in the Northern and Eastern Provinces. Colombo: Government of Sri Lanka.

O'Donnell, Guillermo. 1999. "Horizontal Accountability in New Democracies." In The Self-Restraining State: Power and Accountability in New Democracies, eds. Andreas Schedler, Larry Diamond, and Marc F. Plattner, 29-52. Boulder, CO: Lynne Rienner.

OHCHR (Office of the United Nations High Commissioner for Human Rights). 2015. "Report of the OHCHR Investigation on Sri Lanka (OISL)." A/HRC/30/CRP2, September 16. http://www.refworld.org/docid/55ffb1d04.html (accessed October 27, 2017).

Olsen, Tricia D., Leigh A. Payne, and Andrew G. Reiter. 2010. Transitional Justice in Balance: Comparing Processes, Weighing Efficacy. Washington D.C.: United States Institute of Peace.

Olsen, Tricia D., Leigh A. Payne, Andrew G. Reiter, and Eric Wiebelhaus-Brahm. 2010. "When Truth Commissions Improve Human Rights." International Journal of Transitional Justice 4 (3): 457-476.

Pinto-Jayawardena, Kishali. 2010a. Still Seeking Justice in Sri Lanka: Rule of Law, the Criminal Justice System and Commissions of Inquiry Since 1977. Bangkok: International Commission of Jurists.

Pinto-Jayawardena, Kishali, ed. 2010b. A Legacy to Remember: Sri Lanka's Commissions of Inquiry. Colombo: Law and Society Trust.

President Chandrika Bandaranaike Kumaratunga. 1995. "Commission of Inquiry into the Involuntary Removal or Disappearance of Persons." The Gazette Of The Democratic Socialist Republic Of Sri Lanka, 855/18, 19, 20, January 25.

Schedler, Andreas. 1999. "Conceptualizing Accountability." In The Self-Restraining State: Power and Accountability in New Democracies, eds. Andreas Schedler, Larry Diamond, and Marc F. Plattner, 13-28. Boulder, CO: Lynne Rienner.

Southern COI (Commission of Inquiry). 1998. Final Report of the Commission of Inquiry into the Involuntary Removal or Disappearance of Persons in the Western, Southern and Sabaragamuwa Provinces. Colombo: Government of Sri Lanka.

Special Rapporteur on the Promotion of Truth, Justice, Reparation and Guarantees of NonRecurrence. 2013. "Report to the Human Rights Council." A/HRC/24/42, August 28. http://www.ohchr.org/EN/HRBodies/HRC/RegularSessions/Session24/Pages/ ListReports.aspx (accessed October 27, 2017).

WGEID (Working Group On Enforced Or Involuntary Disappearances). 1999. "Report of the Working Group on Enforced or Involuntary Disappearances." Geneva. E/ CN.4/2000/64/Add.1, December 21.

Wiebelhaus-Brahm, Eric. 2010. Truth Commissions and Transitional Societies: The Impact on Human Rights and Democracy. London: Routledge. 
Carlos Fernandez Torne is a consultant with the Office of the United Nations High Commissioner for Human Rights (OHCHR), researching how transitional justice measures contribute to the prevention of gross violations and abuses of human rights and serious violations of international humanitarian law. Carlos holds a Ph.D. in International Relations from the Universitat Autònoma de Barcelona, a DEA in Peace and International Security from the Instituto Universitario Gutiérrez Mellando, National University of Distance Education, and a MA in International Relations from the Barcelona Institute of International Studies. This article is based on his Ph.D. thesis finalized in May 2017. Previously, Carlos has been working as a lawyer in Barcelona, Spain, and as a human rights officer with the OHCHR in Nepal, where he lived between 2008 and 2012. Carlos is the Chair of the Steering Committee of the Standing Group on Human Rights and Transitional Justice of the European Consortium for Political Research (more at: www.tjasia.org).

Submitted: September 8, 2016; Revised: April 25, 2017; Accepted: October 10, 2017 
